\title{
RELATIONSHIP BETWEEN WOMAN VOTERS' CHARACTERISTICS AND PARTICIPATION IN POLITICS TO THEIR PREFERENCES
}

Jurnal Analisa Sosiologi

Juli 2021, 10 (Edisi Khusus

ICOSAPS): 289-312

\author{
Ni Wayan Suarmini ${ }^{1}$, Kartika Nuswantara ${ }^{2}$, Ismaini Zain ${ }^{3}$, Gita Widi \\ Bhawika $^{4}$, Nisfu Asrul Sani ${ }^{5}$
}

\begin{abstract}
Discrepancies between the number of women voters and their low legislative representation is an interesting topic of study. The laws and regulations on parties' eligibility for elections have assigned the proportions of women candidates. These laws have been reformed continuously during elections. However, the result remained the same until the recent 2019 election. This contradicts the reality that the number of women voters, which is more than half the total population, should supply the threshold quota. Therefore, this study examines the relationship between women's preferences and other elements, including voters' characteristics and their participation in political organizations. Online questionnaires were distributed to elicit responses from 1,042 women voters. The analysis of data was performed using descriptive and inferential statistics. Primarily, inferential statistics were used to examine the relationship between the variables utilizing the Chi-Square Test of Independence. The findings confirmed that more women voted for male candidates. However, regardless of occupation, women are interested in joining political parties and assuming leadership roles. Due to the snowballing sampling procedure, it is difficult to generalize the findings of this research. For this reason, future research should target the respondents that have frequently participated in elections to accommodate more generalized findings.
\end{abstract}

Keywords: woman voters, under-representation, woman legislative candidates

\footnotetext{
Abstrak

Kesenjangan antara jumlah pemilih perempuan dengan keterwakilan legislatif yang rendah menjadi topik kajian yang menarik. Undang-undang dan peraturan tentang kelayakan partai untuk pemilihan telah menetapkan proporsi kandidat perempuan. Undang-undang ini telah direformasi terus menerus selama pemilu. Namun, hasilnya tetap sama hingga pemilu 2019 baru-baru ini. Hal ini bertolak belakang dengan kenyataan bahwa jumlah

1,2,3,4,5 Institut Teknologi Sepuluh Nopember

2 tika@mku.its.ac.id

Artikel yang diterbitkan Jurnal Analisa Sosiologi pada edisi khusus ICOSAPS ini telah memenuhi syarat-syarat karya ilmiah, diproses sama seperti pada penerbitan non edisi khusus (terbitan normal), dipresentasikan di International Conference on Social and Political Sciences (ICOSAPS) "Strengthening Resilient Society in the Disruptive Era" yang diselenggarakan oleh Fakultas Ilmu Sosial dan Politik Universitas Sebelas Maret Surakarta pada tanggal 7-8 Oktober 2020.
} 
pemilih perempuan yang lebih dari separuh jumlah penduduk harus memenuhi ambang batas kuota. Oleh karena itu, penelitian ini mengkaji hubungan antara preferensi perempuan dengan elemen lainnya, termasuk karakteristik pemilih dan partisipasi mereka dalam organisasi politik. Kuesioner online dibagikan untuk mendapatkan tanggapan dari 1.042 pemilih perempuan. Analisis data dilakukan dengan menggunakan statistik deskriptif dan inferensial. Terutama, statistik inferensial digunakan untuk menguji hubungan antara variabel menggunakan Uji Independensi ChiSquare. Temuan menegaskan bahwa lebih banyak perempuan memilih calon laki-laki. Namun, terlepas dari pekerjaan, perempuan tertarik untuk bergabung dengan partai politik dan mengambil peran kepemimpinan. Karena prosedur pengambilan sampel bola salju, sulit untuk menggeneralisasi temuan penelitian ini. Untuk alasan ini, penelitian masa depan harus menargetkan responden yang sering berpartisipasi dalam pemilu untuk mengakomodasi temuan yang lebih umum.

\section{Kata kunci: Pemilih Perempuan, Keterwakilan, Caleg Perempuan}

\section{INTRODUCTION}

The history of women's representations of Indonesian democracy has led to further struggles to gain the threshold quota. Indonesia has been urged by the United Nations to allow $30 \%$ quotas of women in legislatures (Benlamlih, 2010). However, the nation continuously fails to register the threshold quota of women's representation in the legislature. Paradoxically, the country's population comprises a higher number of potential woman voters, as reported by CNN Indonesia in 2019 (https://www.cnnindonesia.com/nasional/20181215171713-32-353929/).

Women voters are higher in numbers than their male counterparts. Based on national statistics data, the total number of male and female voters is 96,271,476 and 96,557,044, respectively, suggesting that women should easily win elections. Additionally, women have received tremendous support from political organizations to win in the legislative elections.

Table 1: Proportions of Women Legislative Candidates in 2019 Election

\begin{tabular}{ccc}
\hline Indonesia Political Parties & Number (n) & Percentage (\%) \\
\hline PKB & 220 & 38.26 \\
\hline GERINDRA & 211 & 36.70 \\
\hline PDIP & 215 & 37.59 \\
\hline Golkar & 217 & 37.80 \\
\hline Nasdem & 221 & 38.43 \\
\hline Garuda & 111 & 48.26 \\
\hline Berkarya & 212 & 38.48 \\
\hline PKS & 210 & 39.62 \\
\hline Perindo & 221 & 38.91 \\
\hline PPP & 233 & 42.06 \\
\hline
\end{tabular}




\begin{tabular}{ccc}
\hline PSI & 274 & 47.74 \\
\hline PAN & 220 & 38.26 \\
\hline Hanura & 178 & 41.40 \\
\hline Demokrat & 223 & 38.92 \\
\hline PBB & 161 & 40.35 \\
\hline PKPI & 77 & 56.20
\end{tabular}

Source: https://mmc.tirto.id/image/2018/11/22/perempuan-di-kursiparlemen--mild--fuad-01.jpg

Table 1 shows that political parties eligible for the 2019 elections nominated women as legislative candidates far surpassing the threshold quota. Prihatini (2018b) unraveled that the portions provided to nominate women as legislators in the 2019 election were genuine, according to male and female lawmaker respondents. More than $60 \%$ of female and $50 \%$ male lawmakers under survey stated that political parties nominated women candidates to the legislative seats, not just for party eligibility. In contrast, the nominations were meant to support women in gaining more votes and meet the minimum quota in the legislative chambers. Furthermore, Indonesian laws have guaranteed women representation by issuing Laws No. 2 and No. 10 of 2008.

Regarding women's representation, the 2019 election marked the beginning of elected female representatives seating in the legislative chambers. The total number of women representatives is 118 out of the 575 legislators. This translates into $20.52 \%$, which is closer to the threshold $30 \%$ quota, indicating positive progress of Indonesia's democracy ((Hillman, 2017)Hillman, 2017a; Mlambo \& Kapingura, 2019 Prihatini, 2018b, 2018a; Prihatini, 2019a; Putri, 2017; Rahmawati, 2014; Rhoads, 2019; Siregar, 2005). Previous research identified some factors leading to women's underrepresentation. One of the most overarching factors is dealing with patriarchy ideology (Benlamlih, 2010; Indar Parawansa, 2002; Hillman, 2017; Jakimow, 2018). Patriarchism has been implanted into Indonesians and keeps reviving to the present day. Another factor is related to culturereligion-social justifications (Prihatini, 2018b, and Siregar, 2005). Cultural norms and religious lessons have made women assume roles behind their husbands, diminishing the idea of gender-based equality. Finally, another factor is contributed by the women themselves. More qualified and educated women demonstrate low interest and a less profound attitude towards politics (Benlamlih, 2010; Davies, 2010; Prihatini, 2019b).

Besides those factors, preferences are yet another critical issue. Primastika (2018) and Siregar (2005) mentioned that female voters only had a little knowledge about female candidates. This is because the female candidates offered less propagation to the voters. In contrast, male candidates propagated themselves to their voters with big posters and other 
varied programs, which made them familiar. Similarly, Prihatini investigated young voters' preferences. Findings demonstrated that young voters were fond of male candidates because they tended to work as lawmakers compared to their female counterparts. Furthermore, religious justifications were allegedly used to allow men more freedom to perform their jobs outside the house (Prihatini, 2018a).

There has no end to studying women's under-representation in Indonesia's democracy. Although the last election exhibited a slightly slanting trend, whatever happened should not repeat, considering the high population of women, their education in this modern era, and the jurisdiction support. The present study finds this as a challenge to seek more evidence directly from (women) selves. It is presumably true that their decision to choose depends on their existing characteristics. Also, the decision may be based on (their) experience and participation in politics and their knowledge of the importance of their representation.

Due to the absence of such, this study investigates the relationship between woman-voters preferences to their characteristics, participation, and knowledge about legislative representation. To seek the evidence, the study provides descriptive pictures regarding voters' characteristics, politics, participation, and preferences. An inferential statistic is used to test the Null hypothesis below:

Ho1: There is no significant relationship between voters' characteristics and preferences

Ho2: There is no significant relationship between political participation and preferences

\section{Trends of women representations in Indonesia General Elections}

Speaking about women's representation of Indonesia's democracy, a recapitulation wraps up election results from 3 different eras, the New Order, transition, and modern democracy.

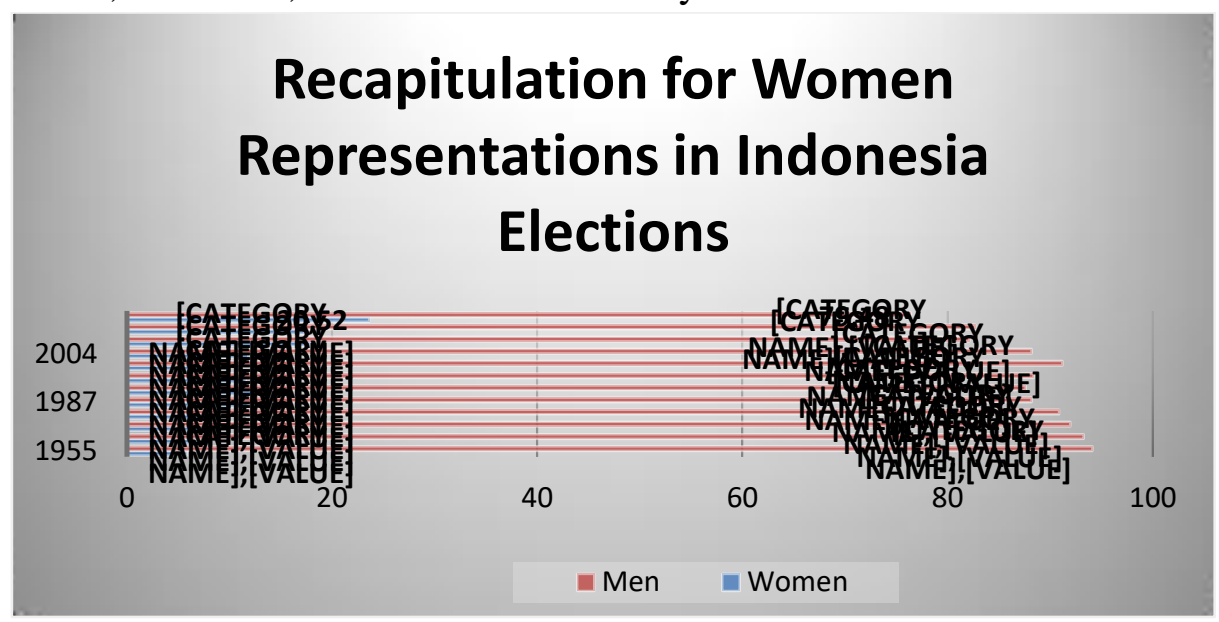

Figure 1. Women in the Legislatures as shown in the Elections Recapitulation 
Figure 1 depicts the fluctuations of women's representation in the era of the New Order extended from 1955 to 1997 . There had been 6 elections in 1971, 1977, 1982, 1992, and 1997. During the era, the legislative representation of women was far below the threshold, with quotas ranging between $6 \%$ to $12 \%$. The next era demonstrated not a far different result. It was only once that an election was held in 1999 and resulted in a very low quota of $8.8 \%$. A better result was seen in 2004, in which the quota reached $23.6 \%$. However, it again insignificantly dropped to $20.52 \%$ in 2019.

The two elections for modern democracy could become an early milestone for women's representation in the legislature.

\section{The History of Indonesian Women' s Participation in Politics}

The fluctuating recapitulation became the underlying foundation. Therefore, history should be revisited.

\section{a. The New Order Era}

The former Indonesian President, Mr. Soeharto, made women played a pivotal role as mothers and homemakers to ensure social stability, implement development plans, and reduce birth rates during that regime (Blackburn, 2004). Unfortunately, this was not in the democracy drama. The gender ideology was propagated to imply that the family was the nation's stronghold. The country's development was determined by the quality of families, in which the Indonesian mothers played a key role. Furthermore, it was assumed that the family welfare would establish that of the nation. Therefore, the administration prioritized women's role as the basis of achieving noble tasks by leading families as companions to husbands. According to Robinson (2008), the philosophy underlining the ideology was linked to elite Javanese norms, which placed women as kanca wingking ( a husband's partner providing support). Other terminologies with similar notions included what was proposed and used in studies like ibuism (Suryakusuma, 2006) and kodrat (Kusmana, 2015).

Women actively propagated the nuclear family by conforming to the Western middle-class housewife role and selflessly serving their husbands, family, and the state. They proliferated government programs aimed at controlling the birth rate using Keluarga Berencana (Family Planning). Furthermore, Darma Wanita (DW) was created for women whose husbands worked as civil servants and linked to other similar social organizations such as Pembinaan Kesejahteraan Keluarga, or PKK (Family Guidance Movement). The organizations were run in the community context but controlled by the Minister of Internal Affairs. They were established under the same mission but allotted to two different areas. DW was established in government offices to make the wives help their husbands' careers. However, it was branched and linked to PKK, which was established at all society levels. To avoid dichotomy, the wives of state officials (DW) were 
used to organize PKK. This enabled the Government to easily control women's movement and, at the same time, direct them away from its desired goals (Jakimow, 2018). These programs succeeded in camouflaging the original gender ideology mission to propagate natural patriarchal authority on the family and maintain women's subordinate status.

The era is seemingly succeeding in stereotyping women as secondary after men. Women's participation was very narrow in this era. This made Indonesia's regime criticized and pressurized by international forums such as the United Nations for failing to observe gender equality in governance. In response, the regime created a Ministry for Women's Role, which was first introduced as a junior ministry in 1978 during the International Decade for Women (1975-85) (the first and the last female minister appointed up until then). This was aimed at obtaining a positive international image of the regime. The move was effective because the country was invited to international conferences on women and United Nations bodies, such as UNICEF. Moreover, the ministers appointed tended to have a background in Kowani-Indonesian Women Congress (Blackburn, 2004; Suryakusuma, 2006; Jakimow, 2018). However, in 1983, the Ministry was officially made a substantial Cabinet department. Subsequently, it became dependent on other departments, such as Health and Education. In consequence, the role of women was again diminished. Therefore, the regime again aligns with an ideology that seats women in a weak position.

From that time on, they started to radically object and criticize the regime's policies of the women's movement. In response to this situation, the regime diverted its political will. They attempted to win women's sympathy by promoting a new ministry, as they established the Ministry for Women's Role that was. However, the ministry was used to obtain a positive image of the government against the movement and international norms. Therefore, the better-educated staff in this department started adjusting to international rhetoric on women's rights. Moreover, they acted as a killing virus within the government's bureaucracy by introducing new ideas that often contradicted the state's gender ideology (Robinson, 2008). With the rapid economic growth and more educated women, gender ideology was finally objected to. As a result of the country's rapid economic growth, some educated women independently viewed their role in society. They wished to compromise the list proliferated by the governmentdominated official women's movement represented by Kowani. New independent organizations were declared in collaboration with strong human-rights groups of the 1980s onwards. More campaigns were conducted on radical issues such as the rights of women factory workers (Blackburn, 1994). Finally, women started to be equally recognized with men, especially in dealing with livelihood. As a result, education has made women reach the same and share with men. The good towards women in this era was only a strategy to control their movement. Therefore, women's 
roles were still minor, while men persistently dominated. In the elections from 1955 to 1997 , women remained in the position far from the threshold quota.

\section{b. Transition Era}

This era came after the 1998 downfall of The New Order. During this time, Prof B. J. Habibie, the former vice of president Soeharto, succeeded the governance before the 1999 election. The women's movement gained more prominence and actively participated in many new developments, such as conducting voter education and campaigning against the rising violence in the country. Habibie Presidency created the National Commission Against Violence Towards Women, headed by Saparinah Sadli. Since then, the women's movement has continuously evolved, with some joining the democratic battle of the 1999 election. Mrs. Megawati Sukarno Putri voluntarily participated in the election because she was one of the prominent women activists that headed the second biggest political party, the Indonesia Democratic Party. Unfortunately, she only managed the second position as the vice president, Mr. Abdurrahman Wahid, popularly known as Gus Dur. The new regime made the women's movement more intriguing due to the full support from the President. Moreover, the President's best santri (Islamic terminology for student), Khofifah Indar Parawansa, was appointed the minister of Women's Role Ministry, which was later changed to the Ministry of Women's Empowerment. Parawansa was elected due to her dedication as a strong feminist and Islamic woman activist (presently elected as the governor of East Java Province for 2019-2024). Under the leadership of Parawansa, the ministry became an independent institution that operated without other departments' interference. Furthermore, Parawansa changed the Family Planning Program's paradigm into Family Planning Commission Board to involve men (i.e., the $B K K B N$ ). Other than mandating women to use contraceptives, men were fostered to practice family planning through options such as vasectomy and the use of condoms. This was aimed at overcoming gender bias and making men and women share equal rights in promoting family planning and welfare. Another dramatic change was the right given to pregnant schoolgirls formerly barred from continuing with their education (Davies, 2010; Robinson, 2008; and Blackburn, 2004)

The most significant struggle for women's equality in Indonesia was prompted through the election of the first woman president, Mrs. Megawati Sukarno Putri, a daughter of the late President Sukarno. Blackburn (2004) mentioned that Mrs. Megawati was a new manifestation of political motherhood. According to this author, Mrs. Megawati Sukarno Putri experienced persecution during the New Order era and yet upheld the image of a popular, well-loved mother at huge campaign rallies. Motherhood was an advantage in both defying the New Order state and creating a 
constituency. Hence, as president, Mrs. Megawati's election confirmed to an international forum that Indonesia had overcome gender bias to foster women's equality in national democracy.

The transition era has brought an illuminating point of women seating in the legislature chambers. This marks the beginning of women successively assuming leadership roles in the country. It was not long before this era that a woman president was elected. However, the legislative percentage of woman representatives remains not yet achieved. At least, the era has offered new hope for women gaining their representation of the legislature in future regimes.

\section{c. Indonesia Modern Democracy}

This era signifies the awakening of women as leaders. The country was for the first time led by a woman president, Mrs. Megawati Soekarno Putri. Despite objections to some Islamic parties (Doorn-Harder, 2002), Megawati proved strong by leading the country and party until today. The presidency position has made Megawati to pioneer for women feminists and activists in Indonesia and eliminated stereotyping them as secondary citizens after men. Moreover, after the presidency, Megawati is to continue navigating the party to win the votes in the last two elections and support Mr. Joko Widodo as president

Mrs. Megawati opened a new horizon as a woman that simultaneously leads the country and manages the biggest party. Unfortunately, Mrs. Megawati's success as a leading woman in politics has not significantly increased women's participation in politics. The percentage of women in the legislature is still $30 \%$, which is lower than the desired quota (Haq, 1995). Women's representation is mandatory since they are exerted to strive for their rights and children. They should also protect them through more women and children-oriented laws (Bush and Bush, 2011; and Kenworthy and Malami, 1999).

The elected woman president has marked the awakening of women in democracy as well as politics. This is a barometer for women to start fighting and win votes in the elections. During this era, there were two elections hosted in 2014 and 2019. Although the threshold quota was still not achieved, the trends stayed inclining. This implies a phase of Indonesia's politics, where women's representation starts elevating. It indicates hope for Indonesian women to achieve their representation shortly.

Several studies have been conducted on women's representation of Indonesia's legislatures. However, there is still limited data on the characteristics of Indonesian woman voters that might be attributed to their under-representation. Therefore, this study bridges the gap to enable women to achieve the intended quota in future elections and assume more active roles in politics. 


\section{METHODS}

This is a descriptive study that unravels the issues behind women's underrepresentation as legislative candidates during Indonesia's elections. Descriptive analyses were conducted to elicit facts regarding women voters' participation and preferences in politics. The relationship between preferences, characteristics, and participation of women in politics was investigated using inferential statistics. The Chi-Square Test of Independence was employed to determine the relationships.

\section{Sample}

A total of 1,042 women voters participated in this study. They were sampled based on their voting eligibility. The selected participants were women aged at least 17 years old since, at this age, a citizen is eligible to vote. The recruited respondents were classified into 3 age groups. The first group comprised women aged between 17 and 29 with the assumption that they could vote at least once in legislative elections. The second group's age ranged between 30 to 49 years old, assuming that they could participate in at least 3 to 6 elections. The third group consisted of women aged above 50 years, assumed to have lived during more than 6 elections. From the recruitment conducted using Google Form online, the first, second, and third groups obtained $80.1 \%, 14.1 \%$, and $5.8 \%$, respectively. Further demographic descriptions are shown in Table 2.

\section{Procedures}

Respondents were recruited from all provinces in Indonesia. However, due to a limited network, this study could only reach women from 12 out of the 34 provinces. East Java province contributed $54 \%$ of the total 1,042 respondents. This was possibly due to the distribution procedures. The data of women in their institutions were used during questionnaire distribution, despite using more information from social media platforms. Snowball sampling was used to approach women with potential filters determined for the sake of the study objective.

Table 2 Distributions of Participant Demographics Description by Percentage

\begin{tabular}{|c|c|}
\hline Variable & Percentage \\
\hline \multicolumn{2}{|l|}{ Age Group } \\
\hline $17-29$ & 80.1 \\
\hline $30-49$ & 14.1 \\
\hline $50+$ & 5.8 \\
\hline \multicolumn{2}{|l|}{ Province of Origin } \\
\hline Aceh & 2.69 \\
\hline Bali & 1.15 \\
\hline
\end{tabular}




\begin{tabular}{|c|c|}
\hline Variable & Percentage \\
\hline Banten & 4.51 \\
\hline Bengkulu & 0.86 \\
\hline DKI Jakarta & 8 \\
\hline Gorontalo & 1 \\
\hline Western Java & 12 \\
\hline Central Java & 5 \\
\hline Eastern Java & 54 \\
\hline Western Kalimantan & 0.58 \\
\hline Southern Kalimantan & 0.67 \\
\hline Central Kalimantan & 0.29 \\
\hline \multicolumn{2}{|l|}{ Education Background } \\
\hline Primary School & 0 \\
\hline Junior High School & 1 \\
\hline Senior High School & 71 \\
\hline Diploma & 3.6 \\
\hline Bachelor & 19.5 \\
\hline Master & 3.7 \\
\hline Doctor & 1 \\
\hline \multicolumn{2}{|l|}{ Employments } \\
\hline Employed & 20 \\
\hline Not employed & 80 \\
\hline \multicolumn{2}{|l|}{ Occupation Types } \\
\hline Civic servant & 15 \\
\hline Company Employee & 28 \\
\hline Teacher & 22 \\
\hline Lecturer & 8 \\
\hline Entrepreneur & 20 \\
\hline Medical personnel & 2 \\
\hline Others (labor, retired, contract) & 5 \\
\hline \multicolumn{2}{|l|}{ Marital Status } \\
\hline Married & 19.87 \\
\hline Not Married (Single) & 78.50 \\
\hline Ever Married & 1.63 \\
\hline
\end{tabular}

\section{Instrument}

An online questionnaire using Google Forms was designed based on the literature review of women's political preferences to Bahasa, Indonesia (Benlamlih, 2010; Halim, Muhlin, \& Salam, 2018; Hillman, 2017b; Prihatini, 2018a; Prihatini, 2019a; Siregar, 2005). The survey consisted of the introduction and respondents' demographic descriptions, women's participation in politics, and their preferences. The link to the questionnaire was distributed among the authors' network of email, Facebook, and WhatsApp. The filter encompassed criteria of eligibility by age (at least 17 
years old). Using the snowball sampling technique, the online questionnaire received responses from 1,042 women respondents. The link to the online questionnaire was made available during February-April 2020. After receiving a total of 1,042 responses, access to the forms was closed, and the coding of data into a meaningful analysis began.

\section{RESULT AND DISCUSSIONS}

\section{Result}

\section{Descriptive Analysis of Woman-Voters' Participation in Politics}

Questions on the respondents' demographic descriptions, including their age, the province of origin, education background, employment, occupation, and marital status were first elaborated as depicted in Table 2. The respondents' responses to the questions were figured out about their participation in the recurring elections of Indonesia. This information was useful since the community's participation in elections contributes to a positive value of national democracy (Halim, Muhlin, \& Salam, 2018). The respondents' participation was determined by the frequency of joining the elections and taking part in political organizations. Also, it was determined by their response to political issues and knowledge about women's representation.

This section inquired the frequency of respondents' participation in the 6 elections since the New Order for the modern democratic era. Responding to the question on frequency, Figure 2 displays varied frequencies ranging from 1 to 6 times. The highest percentage is occupied by $59 \%$ of respondents with experience to join the election only once. This is due to the age of the respondents that were only eligible for the election in 2019.

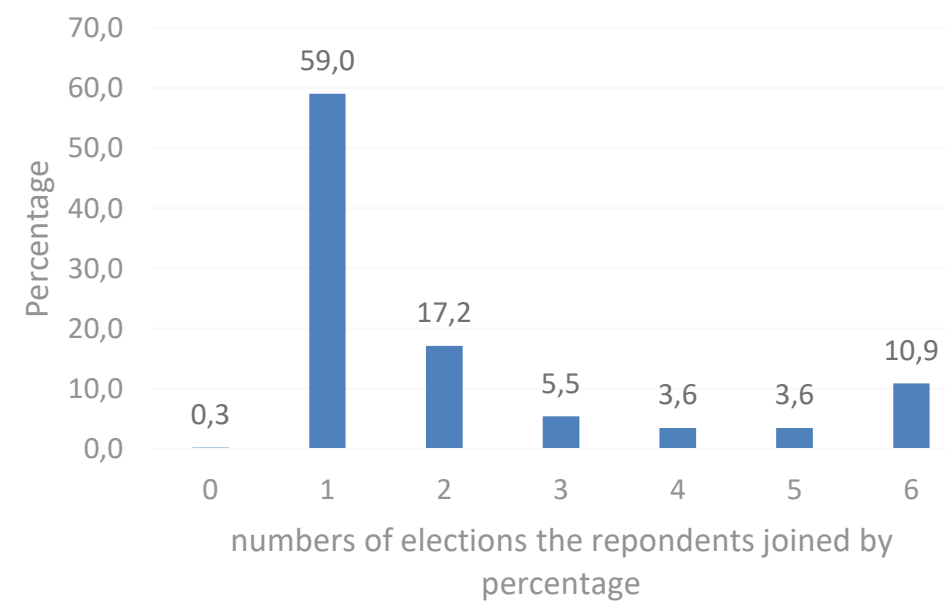

Figure 2: Election Participations by Percentage

Secondly, this section sought respondents' participation in political organizations. It questioned whether they joined any political organizations 
or not, and the result is depicted in Figure 3. Among the respondents, 12 $(1.15 \%)$ admitted to having actively participated in a political organization. These respondents came from the age group of 18-55 years. Concerning educational background, they varied from High School, University, and even Doctoral graduates. They comprised 58.3\% from High School, 33.3\% from University, and one Doctoral graduate.

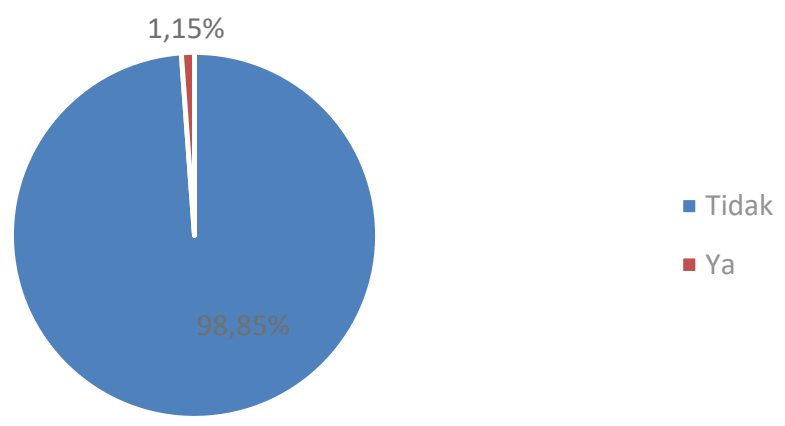

\section{Figure 3: Participation in political Organization}

Active participants of an organization responded to questions about their participation. Responses to this question resulted in 5 classifications, including participant, member, cadre, administrator, and once-administrator. In percentage presentations, $50 \%$ of the respondents were active members of the organization, $25 \%$ were inactive, while the cadre, administrator, and once-administrator occupied $8.33 \%$ (Figure 4).

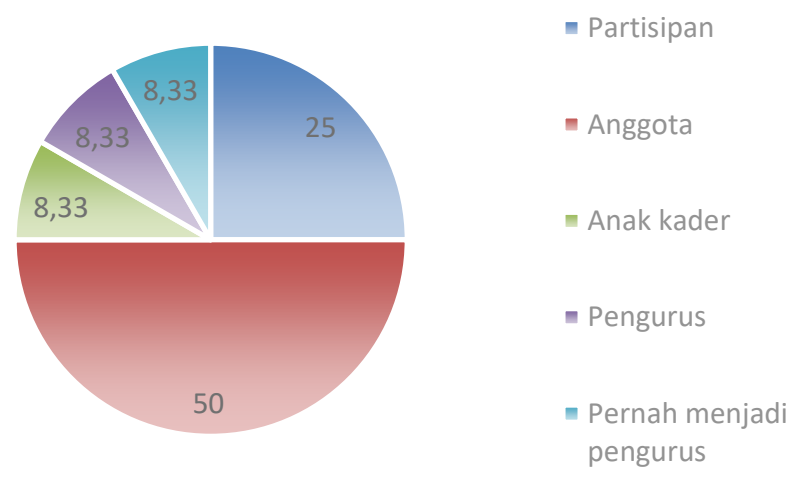

Figure 4: Status in Political Organization

The administrator (pengurus) or ex-administrator (pernah menjadi pengurus) responded to the question of leadership. It inquired whether they had ever been a leader in the organization or not. From the result in Figure 5,7 respondents $(57 \%)$ admitted to having been leaders in the party or organization, out of which 2 were housewives. This is an interesting phenomenon, although it needs more data to be generalized. These women overcome the stigma that a housewife is powerless and comes second after man (Blackburn, 1994; Jakimow, 2018; Kusmana, 2015; and Suryakusuma, 
2006). The ability to lead a political party undeniably grows when women are given leadership opportunities like men.

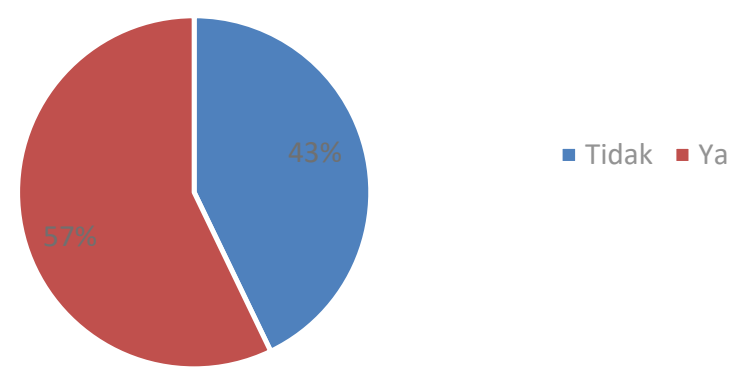

\section{Figure 5: Women Political Leader by Percentage}

Regarding political participation, the section investigates women's response (responses) to political issues. The survey reveals that $89 \%$ of respondents speak their mind, $11 \%$ remain silent and never express their aspirations, as displayed in Figure 6. This shows that women have started to courageously express their political knowledge, which implies that they understand politics to an extent.

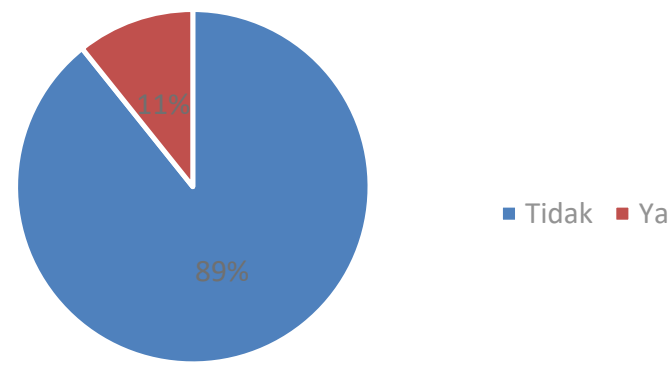

Figure 6: Women's Political Knowledge as the underlining courage to speak about politics

Pertinent to that question, there are some ways of speaking about politics in public. There are $53 \%$ using social media, $14 \%$ through the discussion forum, and $32 \%$ choosing mass demonstrations, while $1 \%$ is unidentified (Figure 7). 


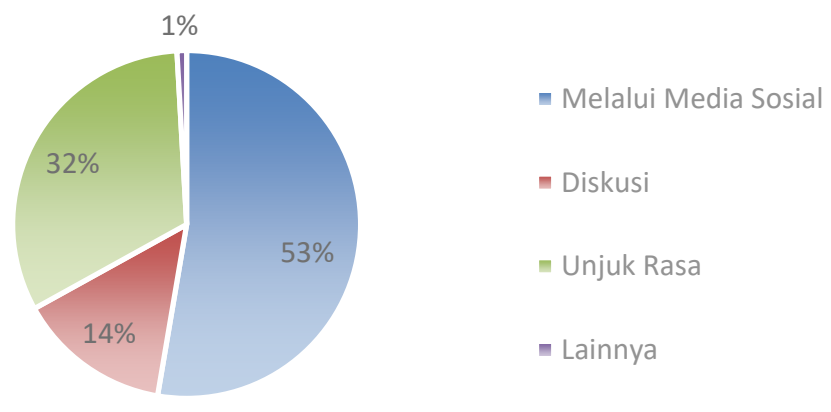

\section{Figure 7: Ways of expressing a political aspiration}

The courage to speak about political issues is related to the existing knowledge (Dolan \& Lynch, 2016; Halim et al., 2018; and Prihatini, 2018a). Hence, political knowledge helps people to determine how they cast their votes. The last question in (about/on) this section is on the political knowledge of women voters. The question is limited to their understanding of women's representation quota in (of) the legislative chamber. From the responses, $85 \%$ of the respondents understand the representation, while $14.4 \%$ (Figure 8).

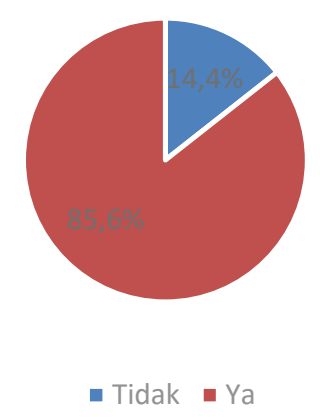

Figure 8: Woman Voters' Knowledge about their Representation

This finding is open for further investigation to determine the characteristics of respondents ignorant of their legislative representation. Hence, this study has shown the characteristics of a group of these respondents, as depicted in table 3.

Table 3: Characteristics of Respondents with less knowledge about representation in the legislature

\begin{tabular}{clrrr}
\hline \multicolumn{1}{c}{ Variable } & & Criteria & $\boldsymbol{\Sigma}$ & \% \\
\hline Age Group & $17-29$ & & 126 & 84 \\
& $30-49$ & 15 & 10 \\
& $50+$ & 9 & 6 \\
\hline \multicolumn{2}{c}{ Total } & & $\mathbf{1 5 0}$ & $\mathbf{1 0 0}$ \\
\hline Place of Origin & Java & 22 & 14,6
\end{tabular}




\begin{tabular}{|c|c|c|c|}
\hline & Out of Java & 128 & 85,4 \\
\hline \multicolumn{2}{|c|}{ Total } & 150 & 100 \\
\hline \multirow[t]{2}{*}{ Marital Status } & Not Yet Married & 125 & 83,3 \\
\hline & Married/Once Married & 25 & 16,7 \\
\hline \multicolumn{2}{|l|}{ Total } & 150 & 100 \\
\hline \multirow[t]{2}{*}{ Education } & $<$ High School & 121 & 80,7 \\
\hline & University & 29 & 19,3 \\
\hline Total & & 150 & 100 \\
\hline
\end{tabular}

From Table 3, 84\% of women with less knowledge about their legislative representation fall within the age of 17-29 years old (84\%). Most of these women live outside Java and are not yet married. This shows that young female voters dwelling in Java has little knowledge of women's legislative representation. Their little knowledge is that they recently finished their high school education, which is assumed to give them less information on politics. Therefore, they could be less aware that voting for a female legislative candidate increases women's representation. This confirms Prihatini (2018a), that young voters lack knowledge about politics.

Women's participation is summarized in 4 different yet related points. These include frequency joining the elections, participation in political organizations, responding to political issues, and knowledge about their representation. Unfortunately, young voter respondents have a respectively lower degree of percentage of all the 4 mentioned points. However, few woman voters demonstrate their active participation in political organizations. Additionally, they have leadership skills that make them administrators and even nominated as legislative candidates. More interestingly, the women comprise those with a career as well as housewives. This disapproves of the fact that women only assume secondary roles after men (Benlamlih, 2010; Halim et al., 2018; Hillman, 2017a; Prihatini, 2018a; Prihatini, 2019b; Rasyidin \& Aruni, 2016) 


\section{Descriptive Analysis of Woman-Voter Preference in Politics}

The following section in the questionnaire investigates women's political preferences as a core issue in this study. This finding confirms (Blackburn, 1994; Prihatini, 2018a; Rule, 1994; and Suryakusuma, 2006), which stated that female legislative candidates are less favored than male counterparts. Also, this study shows that women voters prefer male candidates. Figure 9 shows that $64.88 \%$ of women voters prefer male

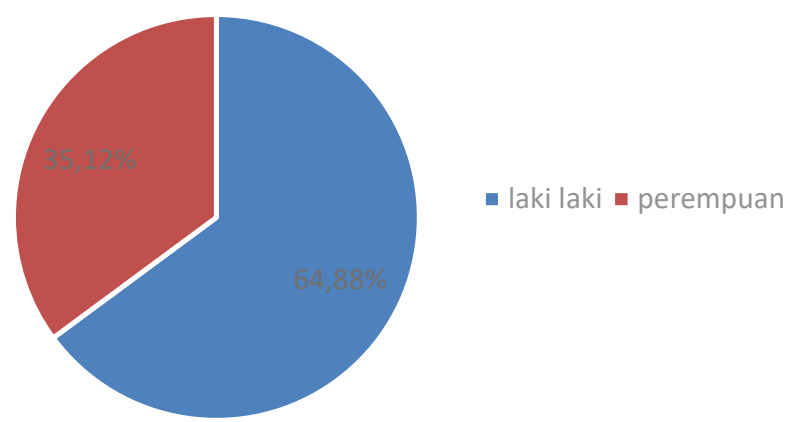

candidates, while only $35.12 \%$ cast their votes for females.

\section{Figure 9: Woman Voters' Preference by Genders}

Regarding the preference, the survey reveals some underpinning reasons for women to choose female candidates or not. Table 4 displays the reasons for votes cast by women. Stigma to seat men in leadership positions remains in $40.4 \%$ of respondents. Only $17.2 \%$ of the respondents agree that women are good leaders. Furthermore, compared to women, men naturally think better and are more reliable in accomplishing political tasks. In this regard, $29.6 \%$ of the respondents settled for men, while $18.5 \%$ opted for women. The other reason is gender equality. Although smaller in percentage, $31.1 \%$ of the respondents chose woman candidates for gender equality. Interestingly, there is a similar reason for both groups of women that vote for female and male candidates. The two groups are less concerned about whether men or women win in the election. These groups occupy about $13-14 \%$. Several respondents claimed that other factors must be considered in determining good leaders, apart from genders.

Table 4: Reasons for Casting Votes based on Genders by Percentage

\begin{tabular}{|c|c|c|c|}
\hline \multicolumn{2}{|c|}{ Women vote for men candidates. } & \multicolumn{2}{|c|}{$\begin{array}{l}\text { Women vote for a woman } \\
\text { candidate. }\end{array}$} \\
\hline Reasons & $\%$ & Reasons & $\%$ \\
\hline Great Leaders & 40,4 & Gender Equality & 31,1 \\
\hline Ways of Thinking & 15,5 & Leadership Ability & 17,2 \\
\hline Responsibilities & 14,1 & Gender-Neutral & 14,8 \\
\hline
\end{tabular}


Gender-neutral

13,4 Empathetic

13,7

Assertive

9,6 Ways of Thinking

12,8

Authoritative

3,3 Responsibilities

Others

3,7 Others

4,6

Total Respondents

676 Total Respondents

366

Total Percentage

(100) Total Percentage

(100)

Pertinent to political preference, this study presents the descriptive manner as depicted in Table 5. In the table, the concept of political preferences of woman voters was measured using 6 indicators.

Table 5: Indicator Distributions of Women Political Preferences

\begin{tabular}{lcccccc}
\hline \multicolumn{1}{c}{ Indicator } & STS & TS & N & S & SS & $\Sigma$ \\
\hline $\begin{array}{l}\text { 1. The legislative chamber } \\
\text { should be seated dominantly by } \\
\text { men legislators }\end{array}$ & 15,0 & 37,0 & 35,0 & 11,0 & 2,0 & 100 \\
\hline $\begin{array}{l}\text { 2. Legislative Chambers have } \\
\text { women legislators to represent } \\
\text { women' population }\end{array}$ & 3,0 & 10,0 & 42,0 & 33,0 & 12,0 & 100 \\
\hline $\begin{array}{l}\text { 3. Women are less capable of } \\
\text { acting as legislators }\end{array}$ & 24,0 & 54,0 & 17,0 & 4,0 & 1,0 & 100 \\
\hline $\begin{array}{l}\text { 4. Woman legislators hardly } \\
\text { defeat man legislators }\end{array}$ & 33,0 & 51,0 & 13,0 & 3,0 & 1,0 & 100 \\
\hline $\begin{array}{l}\text { 5. Women representation must } \\
\text { be achieved }\end{array}$ & 4,0 & 10,0 & 44,0 & 31,0 & 11,0 & 100 \\
\hline $\begin{array}{l}\text { 6. Woman-Voters should vote } \\
\text { for woman candidates }\end{array}$ & 5,0 & 18,0 & 47,0 & 21,0 & 9,0 & 100 \\
\hline
\end{tabular}

From the 6 indicators, a Political Preference variable is formed. From Table 6 , indicators 2, 5, and 6 have a right-leaning trend, while 1, 3, and skews the distribution to the left. This means that from the 6 indicators, women have positive political preferences towards their legislative representation. Indicators 1,3 , and 4 are reverse statements. The score of Women's Political Preference is then determined after the validity and reliability of each indicator are tested.

Before performing a relationship analysis, the validity and reliability tests are used for the political preference variable. The results of testing the validity and reliability are made. Subsequently, the 6 indicators forming political preferences are scored, and a political preference score is obtained. The lowest Political Preference Score is 6, and the highest is 36. The calculation results show that out of 1,042 respondents, 202 of them (19\%) have a lower preference for women representation; on the contrary, while the rest $(81 \%)$ have a high preference (Figure 10$)$. Therefore, the indicator is 
valid and reliable in measuring the respondents' preferences for women's legislative representation. This confirms that women voters prefer male candidates to females.

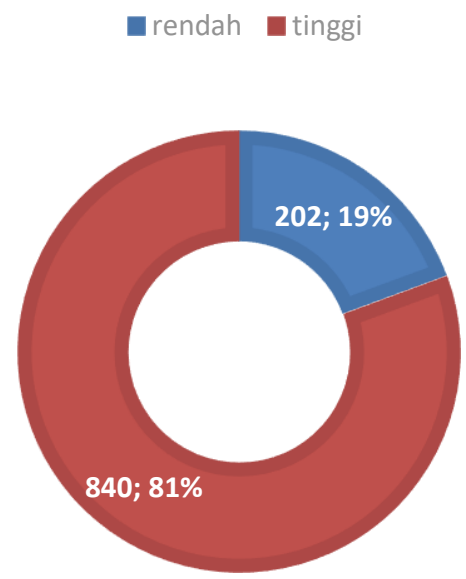

Figure 10: Percentage of Woman-Voters Preferences toward Woman Representations

In summary, this section claims that women's political preferences are limited to their choice of candidates. Based on gender, woman voters prefer male candidates due to the general stereotypes attached to women or men's qualities. Moreover, this is confirmed by the 6 indicators that determined men as more appropriate to be seated at the legislative chambers. In light of women's preferences toward voting for men, this study contributes novel information from what has been figured out by previous studies (Prihatini, 2018a; Rahmatunnisa \& Mariana, 2017; Rhoads, 2019; Siregar, 2005)

Inferential Analysis of relationship between voters' characteristics and participation in politics to Political Preferences

A discussion about Political Preferences on women's legislative representation was conducted with some characteristics of respondents and Election Experience and Participation. From the results of Table 6 on Woman-Voters' characteristics, the proportion of respondents with relatively low and high preference scores is proportional to all variables. This shows that there is no relationship between age groups, domicile, education, work status of women, and one's political preferences. On the contrary, the variables included in the experience and involvement of women in the Election and Representative preference for the Legislature showed a disproportionate tendency (Table 5). This indicates that there tends to be a positive relationship between the experience of participating in 
elections, activeness in political parties, the choice of legislative candidates, and understanding the rules in women's legislative representation.

Furthermore, the hypotheses below were tested with the Chi-Square Test.

$\mathrm{H}_{0}$ : The two variables are independent (No relationship between observed variables)

$\mathrm{H}_{1}$ : The two variables are interdependent (There is a relationship between the observed variables)

Following is the independence test of each variable using the ChiSquare Test. The overall independence test table is shown in Table 6. Based on Table 6, all variables of the respondent's characteristics, including age group, domicile, education, and work status are not significant, indicated with a P-value of more than $\alpha$ of 0.05 or count ${ }^{\wedge} 2$ smaller than $\chi_{-}((0.05$; df) $)^{\wedge} 2$. Hence, all variables of female characteristics have no relationship.

The test results of Table 7 reinforce the indication of dependencies. Out of the 4 variables from the factors of experience and involvement in the Election and Representation in the Legislature, 3 are the experience of participating in the election, the choice of candidates in the legislature, and understanding the rules of women legislative representation. This is indicated by the P-value less than $\alpha$ of 0.05 or calculate ${ }^{\wedge} 2$ greater than $\chi$ $((0.05 ; \mathrm{df}))^{\wedge} 2$. The activity in political parties variable that does not show a significant relationship of women's political preferences.

Table 6 Cross Tabulation of Respondent Characteristics with Political Preferences

\begin{tabular}{lrrrrr}
\hline \multirow{2}{*}{ Variable } & \multicolumn{5}{c}{ Preferences } \\
\cline { 2 - 6 } & & Low & \multicolumn{3}{c}{ High } \\
\cline { 2 - 6 } & & Num & Num \\
ber & \% & ber & \% \\
\hline A. Characteristics of Respondents & & & & & \\
\hline Age Group & $17-24$ & 164 & 81,2 & 671 & 79,8 \\
& $25-49$ & 29 & 14,4 & 118 & 14,1 \\
& $50+$ & 9 & 4,4 & 51 & 6,1 \\
\hline Domicile & Total & 202 & 100 & 840 & 100 \\
& DKI & 16 & 7,92 & 63 & 7,50 \\
& Western Java & 21 & 10,4 & 102 & 12,4 \\
& Central Java & 10 & 4,9 & 43 & 5,9 \\
& Eastern Java & 114 & 56,4 & 453 & 53,9 \\
& Others & 41 & 20,3 & 179 & 21,3 \\
\hline \multirow{3}{*}{ Education } & Total & 202 & 100 & 840 & 100 \\
\hline & Junior High & & & & \\
& and below & 2 & 1,0 & 10 & 1,2
\end{tabular}


High School $142 \quad 70,3 \quad 598 \quad 71,2$

Uni Graduates

$+\quad 58 \quad 28,7 \quad 594 \quad 27,6$

$\begin{array}{lllll}\text { Total } & 202 & 100 & 840 & 100\end{array}$

\begin{tabular}{rrrrrr}
\hline Work Status & Not Work & 158 & 78,2 & 6740 & 80,2 \\
& Work & 44 & 21,8 & 166 & 19,8 \\
\hline Total & 202 & 100 & 840 & 100 \\
\hline
\end{tabular}

\section{B. Participation in Politics}

\begin{tabular}{|c|c|c|c|c|c|}
\hline Experience in joining & & & & & \\
\hline Elections & No & 197 & 97,5 & 833 & 99,2 \\
\hline & Yes & 5 & 2,5 & 7 & 0,8 \\
\hline & Total & 202 & 100 & 840 & 100 \\
\hline participation in & & & & & \\
\hline political organization & No & 199 & 98,5 & 831 & 98,9 \\
\hline & Yes & 3 & 1,5 & 9 & 1,1 \\
\hline & Total & 202 & 100 & 840 & 100 \\
\hline Votes in the Legislative & & & & & \\
\hline Elections & Woman Can. & 172 & 85,2 & 504 & 60,0 \\
\hline & Man Can. & 30 & 14,8 & 336 & 40,0 \\
\hline & Total & 202 & 100 & 840 & 100 \\
\hline Knowledge & & & & & \\
\hline representation & Yes & 38 & 18,8 & 112 & 13,3 \\
\hline & No & 164 & 81,2 & 728 & 86,7 \\
\hline & Total & 202 & 100 & 840 & 100 \\
\hline
\end{tabular}

Source: primer data

Table 7 Dependency Test Results Between Independent Variables and Political Preference

\begin{tabular}{|c|c|c|c|c|}
\hline Variable & $\mathrm{Db}$ & $\chi_{\text {hit }}^{2}$ & $\begin{array}{l}\mathrm{p}- \\
\text { value }\end{array}$ & Descriptions \\
\hline \multicolumn{5}{|l|}{ A. Characteristics of Respondents } \\
\hline 1. Age Group & 2 & 0,784 & 0,676 & No relationship \\
\hline 2. Domicile & 4 & 0,735 & 0,947 & No relationship \\
\hline 3. Education & 2 & 0,145 & 0,930 & No relationship \\
\hline 4. Work Status & 1 & 0,413 & 0,520 & No relationship \\
\hline \multicolumn{5}{|l|}{ B. Participation in Politics } \\
\hline $\begin{array}{l}\text { 1. Frequency of experience in } \\
\text { joining Elections }\end{array}$ & 1 & 3,856 & 0,050 & Relationship \\
\hline $\begin{array}{lr}2 . & \text { Active in } \text { Politics } \\
\text { Organization } & \end{array}$ & 1 & 0,245 & 0,621 & No relationship \\
\hline $\begin{array}{l}\text { 3. Favorite Vote (male/female } \\
\text { can) }\end{array}$ & 1 & 45,196 & 0,000 & Relationship \\
\hline Knowledge & 1 & 3,966 & 0,046 & Relationship \\
\hline
\end{tabular}


Representations

Source: primer data

Of the 3 variables that have a relationship, the Odds Ratio (OR) value is calculated. OR calculation is only performed on variables that have a significant relationship with political preferences. Table 7 shows that the OR value for the experience variable following the election is obtained by calculation $(197 \times 7) /(5 \times 833)$, which is equal to 0.33 . This means that women with a higher frequency in joining elections have a high political preference of 0.33 times than those with a lower frequency. In other words, women experienced with recurring elections have a high political preference of $1 / 0.33$, or 3.03 times compared to those with less experience. Furthermore, the OR value for the favorite candidates in the legislature and knowledge about women's legislative representation is 3.83 and 1.51, respectively. It means that women whose favorite legislative candidates are female have a higher political preference than those who choose the male candidates. When this is reversed, women with a high political preference are 3.81 times electing female legislative candidates than those with low political preferences. Similarly, women who understand women's representation have a 1.51 times political preference compared to those with little knowledge of women's legislative representation.

To determine the political preferences, women vote for specific choices, not because of their characteristics based on their demographic descriptions. Preferences are related to the frequency of women's participation in recurring elections, their favorite candidates, particularly by gender, and their knowledge about the representation quota. The findings reinforce that men's legislative candidates are better elected by a different group of voters, including age, education, and gender.

\section{CONCLUSION}

This paper has demonstrated some key findings to contribute to the literature of Indonesian women's legislative representation. First, woman voters are often thought to have a lower percentage of participation in politics. Contrastingly, this study found that women are capable of leading political organizations, regardless of their occupation. However, this case is not generalized across other contexts. Second, the study reinforces previous findings regarding political preferences. It discusses the reasons leading to preferences. Personal qualities of men and women and perspectives on legislative representation encourage women to present their voices in elections. Finally, the relation of the elements shows that there are links between the frequency of women's participation in recurring elections, their favorite candidates, particularly by gender, and their knowledge about representation quota to women's political preferences. 
This article has several limitations that should be considered for future research. The first limitation relates to the approach to obtaining respondents, the snowball sampling technique. This method has resulted in a sample bias as most of the respondents come from certain specific age groups and friendship networks. Consequently, future research might consider a more inclusive and randomized approach to gather a representative sample that applies to the generalized Indonesian women population.

The other limitation emerges from the questions testing respondents' participation in politics. To gain the expected responses, respondents should include an ample number of women that highly participate in political organizations, such as making the elected woman legislative as the respondents of the future research. Furthermore, there is insufficient information about the political knowledge of woman voters. Therefore, in support of the previous research (Prihatini, 2018a), questions regarding political knowledge should be inserted in the variable. As stated by Prihatini, political knowledge could be a determinant element to help improve the representation of women in the legislature.

\section{DAFTAR PUSTAKA}

Benlamlih, E.-M. (2010). Women Participation in Politics and Government in Indonesia. UNDP Indonesia.

Blackburn, S. (1994). Gender Interests and Indonesian Democracy. Australian Journal of Political Science, 29(3), 556-574. https://doi.org/10.1080/00323269408402312

Blackburn, S. (2004a). Women and the state in modern Indonesia. New York Cambridge University Press. New York: Cambridge University Press.

Blackburn, S. (2004b). Women and the State in Modern Indonesia (1st ed., Vol. 1). Melbourne: Cambridge University Press.

Bush, S. S., \& Bush, S. S. (2011). Organization: International Politics and the Spread of Quotas for Women in Legislatures International Politics and the Spread of Quotas for Women in Legislatures. International Organization, 65 103-137. https://doi.org/10.1017/S0020818310000287

Davies, S. G. (2010). Gender diversity in Indonesia: Sexuality, Islam and queer selves. Gender Diversity in Indonesia: Sexuality, Islam and Queer Selves. Routledge Taylor \& Francis Group. https://doi.org/10.4324/9780203860953

Dolan, K., \& Lynch, T. (2016). The Impact of Gender Stereotypes on Voting for Women Candidates by Level and Type of Office. Politics and Gender, 12(3), 573-595. https://doi.org/10.1017/S1743923X16000246

Doorn-Harder, N. Van. (2002). The Indonesian Islamic Debate on a Woman President. Journal of Social Issues in Southeast Asia, 17(2), 164-190. 
https://doi.org/10.1355/sj17-2b

Halim, R., Muhlin, M., \& Salam, R. (2018). Political participation of communities in the Legislative General Elections (Pemilu). Masyarakat, Kebudayaan Dan Politik, 31(3), 278. https://doi.org/10.20473/mkp.v31i32018.278-290

Haq, M. ul. (1995). Human Development Report 1995: Gender and Human Development. Human Development Report (1990 to present).

Hillman, B. (2017). Increasing Women's Parliamentary Representation in Asia and the Pacific: The Indonesian Experience. Asia and the Pacific Policy Studies, 4(1), 38-49. https://doi.org/10.1002/app5.160

Jakimow, T. (2018). Beyond 'State Ibuism': Empowerment Effects in Stateled Development in Indonesia. Development and Change, 49(5), 11431165. https://doi.org/10.1111/dech.12374

Kenworthy, L., \& Malami, M. (1999). Gender inequality in political representation: A worldwide comparative analysis. Social Forces, 78(1), 235-268. https://doi.org/10.1093/sf/78.1.235

Kusmana, K. (2014). Menimbang Kodrat Perempuan antara Nilai Budaya dan Kategori Analisis. Refleksi, 13(6), 779-800. https://doi.org/10.15408/ref.v13i6.1000

Prihatini, E. S. (2018a). Indonesian young voters: Political knowledge and electing women into parliament. Women's Studies International Forum, 70(June 2018), 46-52. https://doi.org/10.1016/j.wsif.2018.07.015

Prihatini, E. S. (2018b). On The Same Page? Support for Gender Quotas among Indonesian Lawmakers. Asian Social Science, 14(5), 48. https://doi.org/10.5539/ass.v14n5p48

Prihatini, E. S. (2019). Women who win in Indonesia: The impact of age, experience, and list position. Women's Studies International Forum, 72(August 2018), 40-46. https://doi.org/10.1016/j.wsif.2018.10.003

Rahmatunnisa, M., \& Mariana, D. (2017). Women's Political Participation in Indonesia's Reform Era: Local Government Perspective. In International Conference on Ethics in Governance (ICONEG 2016) (Vol. 84, pp. 265-269). Atlantis Press. https://doi.org/10.2991/iconeg16.2017 .60

Rasyidin, \& Aruni, F. (2016). Gender dan Politik: Keterwakilan Wanita Dalam Politik. Unimal Press.

Rhoads, E. (2012). Women's Political Participation in Indonesia: Decentralisation, Money Politics and Collective Memory in Bali. Journal of Current Southeast Asian Affairs, 31(2), 35-56. https://doi.org/10.1177/186810341203100202

Robinson, K. (2008). The Gender Order of the New Order. In Gender, Islam, and Democracy in Indonesia (pp. 68-88).

Rule, W. (1994). Women's s Underrepresentation and Electoral Systems. PS: Political Science and Politics, 27(4), 689-692. 
Siregar, W. Z. B. (2005). Parliamentary representation of women in Indonesia: The struggle for a quota. Asian Journal of Women's Studies, 11(3), 36-72. https://doi.org/10.1080/12259276.2005.11665993

Suryakusuma, J. (2006). Women and Human Rights Under Islam. Gender and Human Rights in Indonesia. 